\title{
Oral acetylsalicylic acid and prevalence of actinic keratosis
}

\author{
JuLIano SCHMITT ${ }^{1}$, HÉLIO MıOT ${ }^{1}$ \\ ${ }^{1}$ Department of Dermatology, Sao Paulo State University, Botucatu Medical School, Unesp, Campus Universitário de Rubião, Botucatu, SP, Brazil
}

Study conducted at Department of Dermatology, Sao Paulo State University, Botucatu Medical School, Unesp, Campus Universitário de Rubião, Botucatu, SP, Brazil

Article received: 04/05/13 Accepted for publication: 08/30/13

Correspondence: Departamento de Dermatologia, S/N Faculdade de Medicina da UNESP Campus Universitário de Rubião Jr. ZIP Code: $18618-970$ Botucatu - SP - Brazil Phone/Fax: +55 14 3880-1267 julivs@gmail.com

http://dx.doi.org/10.1590/1806-9282.60.02.010 Conflict of interest: none

\section{SUMmARY}

Objective: To investigate the influence of a regular oral use of acetylsalicylic acid in the prevalence of actinic keratosis.

Methods: A case-control study with dermatologic outpatients above 50 years of age assessed between 2009 and 2011. Cases were defined as those who had been under regular use of oral acetylsalicylic acid for more than six consecutive months. The assessment focused on: age, sex, skin-type, tobacco smoking, use of medication, occurrence of individual or family skin cancer, and sunscreen and sun exposure habits. Actinic keratoses were counted in the medial region of the face and upper limbs. Counts were adjusted by co-variables based on a generalized linear model.

Results: A total of 74 cases and 216 controls were assessed. The median time of acetylsalicylic acid use was 36 months. Cases differed from controls as to the highest age, highest prevalence of use of angiotensin-converting enzyme inhibitors and fewer keratosis on the face and on the upper limbs $(\mathrm{p}<0.05)$. The multivariate model showed that the use of acetylsalicylic acid was associated to lower counts of face actinic keratosis and upper-limb erythematous actinic keratosis $(\mathrm{p}<0.05)$, regardless of other risk factors.

Conclusion: The regular use of oral acetylsalicylic acid for more than six months was associated to a lower prevalence of actinic keratosis, especially facial and erythematous ones.

Key words: actinic keratosis, acetylsalicylic acid, prevalence, risk factors.

\section{INTRODUCTION}

Actinic Keratoses (AKs) are atypical proliferations of keratinocytes induced mainly by ultraviolet radiation (UVR). Besides its potential (0.6-20\%) for turning into invasive neoplasms, they reflect the accumulated photodamage and indicate a larger risk of developing skin cancers in every region affected by the disease. ${ }^{1-5}$

They are common in sun-exposed areas of elderly fairskinned people, representing $5.1 \%$ of complaints in dermatological consultations in Brazil. In Australia, it is estimated that $40-50 \%$ of the population above 40 years of age presents at least one lesion. ${ }^{6,7}$

Considering that AKs can be models of in-vivo studies of skin carcinogenesis, the identification of factors that can prevent AKs may reveal potential preventive or therapeutic measures related to skin cancer, especially squamous cell carcinoma (SCC). ${ }^{8}$

For decades, the role of non-steroidal anti-inflammatory drugs (NSAI) and mainly acetylsalicylic acid (ASA) has been studied in an attempt to prevent some types of cancer, especially colon and skin cancers. ${ }^{9-11}$ The favorable results in experimental studies and clinical assays were attributed mainly to the inhibition of the cyclooxygenase type-2 enzyme (COX-2), which plays an antiapoptotic, angiogenic, and proliferative role in those neoplasms. ${ }^{12,13}$

ASA is an old and low-cost medication used as antipyretic and anti-inflammatory drug, which acts by the irreversible inhibition of cyclooxygenase 1 and 2. However, it has been recommended in low doses for preventing thromboembolic events. Clinical studies carried out in those populations indicate a reduction in the incidence of some neoplasms, which opened up new therapeutic possibilities. One believes that, besides COX-2 blockage, other pharmaceutical activities of ASA may compose its antineoplastic effect. ${ }^{8}$

The authors aim at investigating the influence of a regular oral use of ASA in the prevalence of AKs in immunocompetent adults above 50 years of age. 


\section{Methods}

We performed a case-control study involving adult subjects above 50 years of age, volunteers, well-informed and consenting, from both sexes, selected among patients from the dermatology outpatient clinic of the Pro-Hansen Foundation - Curitiba, state of Paraná, Brazil - from April, 2009 to September, 2011.

Cases were defined as those who had used a daily minimum $80 \mathrm{mg}$ of oral ASA, more than four days a week, for more than six consecutive months. The controls were those who reported no previous regular use of ASA.

We excluded: patients with signs of immunosuppression, genetic syndromes predisposing to cancer, with a communication deficit, bedridden, with diffuse dermatoses in the tegument, skin phototype V or VI, those who had used other AINEs regularly, those who had interrupted the use of ASA more than 2 months before the interview, those who used systemic or topical retinoids or immunosuppressant medications, those who treated AKs in some occasion or who had been submitted to phototherapic and radiotherapic treatments previously.

A specific systematization of sample collection or proportion between cases and controls was not adopted, and all available patients who fitted the inclusion criteria were consecutively included.

Based on a standardized questionnaire, consenting patients were interviewed and examined by an experienced dermatologist.

Visible AK lesions on predefined areas on the face centrally - and on the forearms, from the elbows to the back of the hands (figure 1) were counted. A skin marker pen was used to help in the counting process. ${ }^{14}$
The main variables analyzed were the number and type of AKs (erythematous or hyperkeratotic) present in the standardized areas of the face and upper limbs (ULs), besides oral use of ASA (time and accumulated load). The other independent variables were: age, sex, skin type, smoking, use of angiotensin-converting enzyme inhibitors (ACEI), occurrence of personal or family skin cancer, sunscreen and sun exposure habits (occupational or leisure).

Quantitative variables were represented by the averages and standard deviation, or medians and quartiles $\left(1^{\text {st }}\right.$ and $3^{\text {rd }}$ ) when normality could not be evidenced by the Shapiro-Wilk's test. ${ }^{15}$ When indicated, the comparison between groups was performed by the Student's t-test or MannWhitney test. Quantitative variables of the count type were compared by a negative binomial regression model. ${ }^{16} \mathrm{Cat}-$ egorical variables were represented by their percentages and compared using chi-square tests or linear trend chisquare tests, in case there was an ordinal characteristic. The correlation between quantitative variables was estimated by Spearman's linear correlation coefficient $\left(\mathrm{r}_{\mathrm{S}}\right){ }^{17}$

First, cases and controls were compared bivariately to show homogeneity of the groups. The effect size of the categorical variables was estimated by odds ratio (OR) and the $95 \%$ confidence interval (CI 95\%). ${ }^{18}$

Later, an exploratory multivariate model of AKs risk based on the generalized linear counting model (negative binomial) was developed consisting of co-variables that reach $p<0.3$. The effect size was represented by $\beta$ estimator of the regression. ${ }^{19}$

Missing data were estimated by the multiple imputation technique. ${ }^{20}$ Two-tailed values of $\mathrm{p}<0.05$ were considered significant. Data were tabulated in MS Excel 2003® and analyzed using SPSS $17.0^{\circledR}$ software. ${ }^{21}$
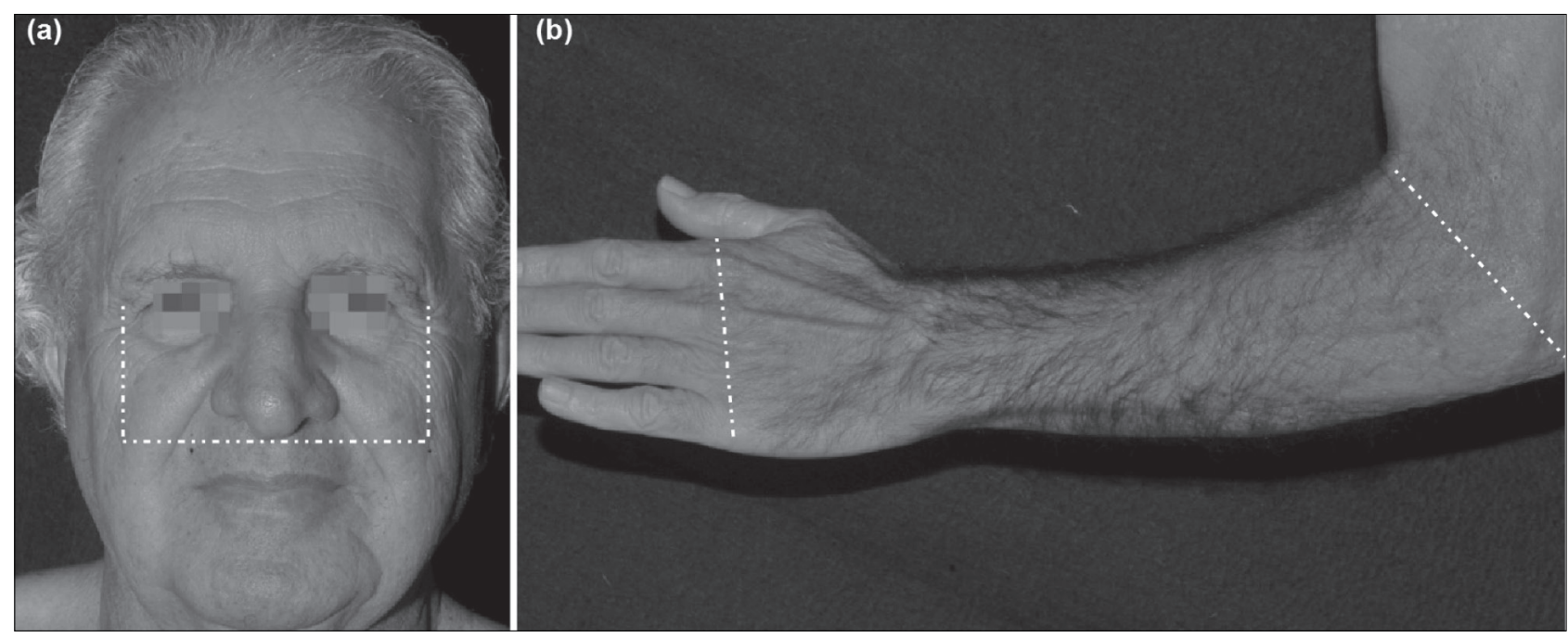

FIGURE 1 Standardized area for counting actinic keratosis on the face (a) and on the forearms (b). 
The sample design was based on a pre-test consisting of 50 cases and 50 controls, and calculated from a multiple regression model, power estimated at 0.8 and bilateral alpha level at 0.05 . According to the estimate of variables in the final model, the smallest sample was considered to be 70 cases and 70 controls. ${ }^{22,23}$

The Project was approved by the institutional review board of the UFPR - Curitiba-Brazil (No 299. EXT.005/2009-03).

\section{RESULTS}

Two hundred and ninety patients were assessed, 74 of them were ASA regular users and 216 were controls. The main clinical and demographic data are presented in table 1. Cases and controls were not homogeneous regarding age, prevalence of the use of ACE inhibitors and number of erythematous AKs.
Among the cases, the median time (quartiles 1 and 3) of ASA use was 36 (17-74) months, $81 \%$ used a daily dose of $100 \mathrm{mg}$, and the median accumulated dose was 27.7 (13-59) g.

The sample median (quartiles 1 and 3 ) of the total number of AKs was 2 (1-5) for face, and 1 (0-3) for ULs; and $80 \%$ of the patients presented at least one AK lesion on the face. A slight correlation was observed between the number of lesions and age both for face lesions and UL lesions $\left(r_{S}=0.3\right.$ and $0.4 ; p^{<0.01)}$. Similarly, the number of facial lesions correlated to the number of UL lesions $\left(r_{S}=0.5 ; p^{<0.01}\right)$.

Eighteen percent of the interviewed people had already received a diagnosis of cancer at some time, and they were those who presented a higher median count (quartiles 1 and 3 ) of AKs both on the face and on ULs (4 $(2-7) \times 2(1-5) ; \mathrm{p}<0.01$ and $2(0-10) \times 0(0-2) ; \mathrm{p}<0.01)$.

TABLE 1. Main clinical and demographic data of cases and controls*

\begin{tabular}{|c|c|c|c|c|}
\hline Variables & Cases & Controls & OR $(95 \% \mathrm{Cl})$ & $\mathrm{P}^{\mathrm{a}}$ \\
\hline Female sex $-\mathrm{N}(\%)$ & $47(64)$ & $149(69)$ & $0.78(0.5-1.4)$ & $0.39^{b}$ \\
\hline Age - average (standard deviation) & $63.5(58-70)$ & $59(55-66)$ & - & $0.00^{c}$ \\
\hline Skin type - N(\%) & & & & $0.41^{\mathrm{d}}$ \\
\hline $\mid-11$ & $20(27)$ & $44(20)$ & $1.40(0.7-2.8)$ & \\
\hline III & $30(41)$ & $98(45)$ & $0.94(0.5-1.8)$ & \\
\hline IV & $24(32)$ & $74(34)$ & 1.0 & \\
\hline Sunburn history $-\mathrm{N}(\%)$ & $44(59)$ & $141(65)$ & $0.78(0.5-1.3)$ & $0.37^{\mathrm{b}}$ \\
\hline Personal history of skin cancer $-\mathrm{N}(\%)$ & $11(15)$ & $41(19)$ & $0.75(0.4-1.5)$ & $0.43^{\mathrm{b}}$ \\
\hline Family history of skin cancer $-\mathrm{N}(\%)$ & $11(15)$ & $28(13)$ & $1.17(0.6-2.5)$ & $0.68^{\mathrm{b}}$ \\
\hline Sun-exposed occupation (last 10 years) - N(\%) & $13(18)$ & $35(16)$ & $1.10(0.6-2.2)$ & $0.79^{\mathrm{b}}$ \\
\hline Sun-exposed leisure - N(\%) & $30(41)$ & $63(29)$ & $1.66(1.0-2.9)$ & $0.07^{b}$ \\
\hline Daily use of sunscreen for more than 2 years - N(\%) & $10(14)$ & $46(21)$ & $0.58(0.3-1.2)$ & $0.14^{\mathrm{b}}$ \\
\hline Regular use of ACEI - N(\%) & $35(47)$ & $39(18)$ & $4.07(2.3-7.2)$ & $0.00^{\mathrm{b}}$ \\
\hline Smoking now - N(\%) & $10(14)$ & $41(19)$ & $0.67(0.3-1.4)$ & $0.29^{\mathrm{b}}$ \\
\hline Face AKs - Median (Q1-Q3) & $1(0-4)$ & $3(1-6)$ & - & $0.02^{\mathrm{e}}$ \\
\hline Erythematous face AKs & $1(0-4)$ & $3(1-5)$ & - & $0.01^{\mathrm{e}}$ \\
\hline Hypertrophic face AKs & $0(0-0)$ & $0(0-0)$ & - & $0.59^{\mathrm{e}}$ \\
\hline UL AKs (Q1-Q3) & $0(0-3)$ & $1(0-3)$ & & $0.03^{\mathrm{e}}$ \\
\hline Erythematous UL AKs & $0(0-3)$ & $1(0-3)$ & - & $0.02^{\mathrm{e}}$ \\
\hline Hypertrophic UL AKs & $0(0-0)$ & $0(0-0)$ & - & $0.72^{\mathrm{e}}$ \\
\hline
\end{tabular}


Regular ASA users were older and had a propensity to perform more sun-exposed leisure activities. There were more retired people among the ASA users $(23 \% \times 10 \%$; OR $=$ 2.6 (1.3-5.3); $\mathrm{p}<0.01)$. Similarly, those who practiced more sun-exposed leisure activities have been more often retired people (24\% x 9\%; OR = 3.3 (1.7-6.5); $\mathrm{p}<0.01)$. When adjusted by retirement, cases and controls did not differ regarding the practice of sun-exposed leisure $(p=0.20)$.

The co-morbidities more significantly associated to ASA regular users were: ischemic heart disease (18\% x $2 \%$; OR = 11.3 (3.6-35.9); $\mathrm{p}<0.01)$, systemic hypertension $(84 \%$ x 39\%; OR $=8.12(4.1-16.0) ; \mathrm{p}^{<0.01)}$, and type 2 diabetes mellitus $(30 \%$ x 6\%; OR $=6.6(3.1-14.0)$; $\mathrm{p}<0.01)$.

Table 2 presents the regression coefficients of face and UL AK scores. There were different patterns of risk variables for each subtype of neoplasm, the influence of the age group and of fair skin-types in the incidence of AKs in all groups, a reduction in the number of face AKs (erythematous and hypertrophic) and erythematous AKs of the ULs among ASA users, in addition to smoking influencing basically the ULs count.

The period of ASA use and the ASA load also correlated to lower counts of face and UL AKs (erythematous and hypertrophic) $\left(\mathrm{p}^{<0.05)}\right.$.

\section{Discussion}

The regular use of ASA was independently associated to lowest AK counts, especially the erythematous forms (face and UL) and the hypertrophic form of the face. The COX2 inhibition is a possible explanation for such phenomenon.

There is an increase of epidermal COX-2 expression in murine skin submitted to UVB radiation, as well as in AK lesions, squamous cell carcinoma (SCC), and basal cell carcinoma (BCC). Similarly, in humans, there is a significantly raised COX-2 expression in SCC lesions (40\%), Bowen disease (22\%), and AKs (31\%) when compared to normal skin. ${ }^{24,26-29}$

TABLE 2 Generalized linear model (negative binomial) to count AKs adjusted by risk co-variables*

\begin{tabular}{|c|c|c|c|c|c|c|c|c|}
\hline \multirow[t]{3}{*}{ Variables } & \multicolumn{4}{|l|}{ Face AKs } & \multicolumn{4}{|l|}{ UL AKs } \\
\hline & \multicolumn{2}{|c|}{ Erythematous } & \multicolumn{2}{|l|}{ Hypertrophic } & \multicolumn{2}{|c|}{ Erythematous } & \multicolumn{2}{|l|}{ Hypertrophic } \\
\hline & estimator $\beta$ & $\mathrm{P}$ & estimator $\beta$ & $\mathrm{P}$ & estimator $\beta$ & $\mathrm{P}$ & estimator $\beta$ & $\mathrm{p}$ \\
\hline Use of ASA & -0.8 & 0.00 & -0.7 & 0.01 & -0.3 & 0.03 & -0.4 & 0.24 \\
\hline Age & 0.1 & 0.00 & 0.1 & 0.00 & 0.1 & 0.00 & 0.1 & 0.00 \\
\hline Female gender & -0.2 & 0.11 & - & - & - & - & - & - \\
\hline Skin type & & 0.00 & & 0.00 & & 0.00 & & 0.00 \\
\hline $\mid-11$ & 1.1 & & 1.7 & & 2.9 & & 2.6 & \\
\hline III & 0.6 & & 1.0 & & 1.3 & & 1.6 & \\
\hline IV & 0.0 & & 0.0 & & 0.0 & & 0.0 & \\
\hline Sunburn history & 0.3 & 0.12 & 1.0 & 0.01 & - & - & - & - \\
\hline Personal history of skin cancer & - & - & 0.7 & 0.16 & 0.3 & 0.10 & 0.5 & 0.15 \\
\hline Family history of skin cancer & 0.3 & 0.25 & - & - & 0.7 & 0.00 & 0.8 & 0.10 \\
\hline $\begin{array}{l}\text { Sun-exposed occupation (in } \\
\text { the past } 10 \text { years) }\end{array}$ & - & - & - & - & 0.4 & 0.09 & 0.8 & 0.03 \\
\hline Sun-exposed leisure & 0.2 & 0.12 & 1.1 & 0.02 & - & - & - & - \\
\hline Regular use of ACEI & - & - & - & - & 0.3 & 0.11 & 0.5 & 0.16 \\
\hline $\begin{array}{l}\text { Daily use of sunscreen for } \\
\text { more than } 2 \text { years }\end{array}$ & - & - & -1.9 & 0.08 & -0.6 & 0.14 & -1.1 & 0.05 \\
\hline Smoking now & - & - & - & - & 0.9 & 0.00 & 1.4 & 0.00 \\
\hline Deviance (model) & \multicolumn{2}{|l|}{216.7} & \multicolumn{2}{|l|}{91.0} & \multicolumn{2}{|l|}{336.2} & \multicolumn{2}{|l|}{145.8} \\
\hline $\mathrm{P}$ (model) & \multicolumn{2}{|l|}{$<0.01$} & \multicolumn{2}{|l|}{$<0.01$} & \multicolumn{2}{|l|}{$<0.01$} & \multicolumn{2}{|l|}{$<0.01$} \\
\hline
\end{tabular}

${ }^{a}$ Composition of each model with variables that result in $\mathrm{p}<0.3$; Model effect: type I analysis.

ACEI = Angiotensin converting enzyme inhibitor; $A K=$ Actinic Keratosis; ULs = Upper limbs

* The actinic keratosis lesions were counted on middle face and dorsal aspect of the forearms and hands. 
Transgenic mice, which promote an elevated COX-2 expression, are more susceptible to UV-induced skin tumors, while COX-2 deficient mice have a tumor rate $75 \%$ lower than normal mice. ${ }^{30,31}$ Besides, it was observed that the presence of inflamed AKs in humans is associated to the progression to invasive diseases in those lesions. ${ }^{32}$

$\mathrm{COX}-2$ and prostaglandin $\mathrm{E} 2$ are positive regulators of tumor proliferation, mainly through Ras/Raf/MAPK, and Pt13K/Akt. ${ }^{33}$ The MAPK pathway, on the other hand, seems to induce COX-2 production generating a positive feedback cycle. ${ }^{34}$ The same pathway may even activate the production of epithelial growth factor (EGF) in colorectal tumors. ${ }^{35}$

Another property of COX-2 related to carcinogenesis is the promotion of tumor angiogenesis. Its expression is correlated to tumor vascularity, capillary density, and synthesis of vascular endothelial growth factor (VEGF). ${ }^{29,36}$ Similarly, in studies with AINE in colon cancer, a production of angiogenic factors dependent on the activity of COX-2 was observed. ${ }^{13}$

In addition to stimulating cell proliferation and angiogenesis, the elevation of COX-2 is related to the resistance to apoptosis in various tumors, such as the colon, breast, lung, and prostate tumors. The activity of those enzymes proved to be correlated to the expression of antiapoptotic proteins of the $\mathrm{Bcl} 2$ family. ${ }^{12,13}$

A decrease in the formation of UV-induced skin tumors in mice that received celecoxib ( $89 \%$ reduction) or indomethacin (78\% reduction) was observed. ${ }^{37,38}$ A reduction in more than $50 \%$ of UVR-induced skin tumors in naked mice receiving nimesulide - a selective inhibitor of COX-2 - was also observed. ${ }^{39}$ Additionally, celecoxib inhibited the growth of melanoma cells, even in strains not expressing COX $-2 .{ }^{40}$

There was a lower risk of SCC $(\mathrm{OR}=0.2)$ and a lower AK count $(\mathrm{OR}=0.5)$ among regular users of AINEs for more than one year, even in low doses. ${ }^{41}$ Similar results concerning SCC were found in a population study with 1.484 participants, observing a risk reduction with various AINEs, mainly ASA, and more strongly for tumors positive for $\mathrm{p} 53$ or with a loss of heterozygosity of the PTCH gene. ${ }^{10}$

In an observational prospective study involving 2.297 participants, Clouser et cols also identified an inverse association between the use of NSAI and SCC and BCC risks. But, in that study, short term use was more protective than long term use. ${ }^{42}$ Furthermore, Asgari et cols did not observe any association between the use of AINEs and SCC risks in an investigation that included 830 North Americans. ${ }^{43}$
The oral use of celecoxib, a selective inhibitor of COX-2, was prospectively evaluated in a study with 240 individuals for preventing SCC and BCC in carriers of 10-40 AKs. After nine months, there were significantly less new SCC $(\mathrm{RR}=0.4)$ and $\mathrm{BCC}(\mathrm{RR}=0.4)$ lesions in celecoxib users, but there was no reduction in the number of AKs. ${ }^{44}$ Coincidentally, a controlled double-blind prospective study observed $20 \%$ less new BCC lesions in carriers of basal cell nevus syndrome after having used celecoxib for three years. $^{45}$

Although the inhibition of COX-2 by ASA occurs in a dose-dependent ratio, the oral use of just $81 \mathrm{mg}$ daily reduces significantly the prostaglandin E2 levels in the distal colonic mucosa justifying that clinic effect under low dosages, as detected in our sample. ${ }^{46}$ Besides, COX-2 independent antineoplastic mechanisms have already been proposed for ASA, such as the activation of the kappa beta nuclear factor (NF- $\kappa \beta)$ and stimulus to the expression of DNA repair proteins such as: hMLH1 and hPMS2. ${ }^{47-49}$

In the present study, the groups were quite similar regarding the variables under study, except for age, prevalence of co-morbidities, frequency of use of ACEI, and a higher report of outdoor leisure activities among cases. Such characteristics were predictable by the fact the ASA indications presuppose cardiovascular diseases, which are more prevalent with aging. Similarly, cases presented more free time for leisure because most of them are retired and can be encouraged to practice physical activities outdoors - such as hiking - for therapeutic and preventive reasons.

In contrast, a more frequent sun-exposed leisure activity and older age should be factors that would increase the incidence of AKs among cases. A lower count of lesions in those patients reinforces the evidence that ASA exerts a protective role in the development of AKs. Moreover, the multivariate analysis did the adjustment for age, sun exposure and skin type and reinforced the low counting of AKs among cases.

Some epidemiological studies have identified a possible antineoplastic effect of ACEI. ${ }^{50,51}$ Such effects would be attributed to a reduction in the angiogenic and tumor growth promoting activities of angiotensin II. In our casuistic, a significant association between the use of ASA and ACEI was observed, for they are medications which are frequently recommended for cardiovascular diseases. Nevertheless, the use of ASA seemed to be associated to a lower count of AK lesions on the face, even when adjusted by use of ACEI. In the analysis of risk factors for AKs, the use of ACEI - the way it was recorded - was not associated to the number of AKs. 
The prevalence of AK was $80.3 \%$ in this sample $(70.3 \%$ for ASA users and $83.8 \%$ for controls; $\mathrm{p}=0.01$ ), and AK counting was higher in proportion to age, to low skin types and associated to the occurrence of skin cancer. Such findings corroborate previous epidemiological observations and refer to a probable increase in the incidence of AKs with the increase in longevity of the population and an increase in leisure activities exposed to direct sun. ${ }^{2,7}$

Variations in the prevalence of AKs observed in various epidemiological studies may be due to the ethnic composition of the population, their sunscreen use and skin-exposure habits, to levels of UV radiation to which they are exposed as well as the counting methodology used by each team. In the region studied - located on parallel 25-South -, the population is constituted mainly by European descents. In addition, the methodology used promoted an active search for lesions, even though they might not to be significant in a specific population consisting of general dermatological patients, contributing to a high prevalence of AKs in the sample.

Tobacco smoking is a well known risk factor for many solid tumors, besides acting as a co-factor in other neoplasms, for example, in case of tumors related to papillomavirus. ${ }^{52,53}$ There are some studies that relate skin cancer to tobacco smoking, especially SCC $(\mathrm{RR}=2.0) \cdot{ }^{54-56} \mathrm{In}$ addition, there is a strong association between tobacco smoking and solitary keratoacanthoma $(\mathrm{OR}=9.1)$, which some authors consider as a well differentiated SCC form. ${ }^{57,58}$

Our data show an association between current smoking and the number of AK lesions on the ULs, but not on the face. The explanation for this would be that in the region of origin of those patients - located approximately 1000 meters above sea level, with a cold climate most of the year - there is better sun protection for the ULs than for the face because of the clothes they wear, which permits a predominant local action of other carcinogens other than UVR. Such finding must be clarified in studies with specific designs.

Besides the different AK patterns on the face and on ULs, that can be justified by the difficulty in quantifying skin screening and skin-exposure habits, we identified differences in the risk profiles for hypertrophic and erythematous AKs. This may be a result of the distribution of hypertrophic lesions, commonly located on the ULs, as well as the fact they occur in smaller amplitude of count than the erythematous ones, reducing the exploratory performance of statistical models. However, it is also possible that hypertrophic AKs present a lower response to ASA, or even that they represent a lighter risk of evolving or even that they already present an invasive character and may be in more advanced stages of carcinogenesis. ${ }^{59}$ Such data suggest that risk factor studies and even clinical assays in AKs must consider the location of lesions and the clinical types when analyzing the obtained results.

There was a negative association between the regular use of sunscreen for more than two years and AK lesions mainly the hypertrophic ones - which reinforces the relevance of sun-exposure in the genesis of AK. The preventive and therapeutic effect of the use of sunscreen on AKs had already been reported $(O R=1.5$ for remission and $R R=0.6$ for incidence), mainly in places and times of year with high levels of UVR. ${ }^{60-62}$

Our study presents some limitations as a result of a possible inaccuracy in the clinical diagnosis of AKs and also because the manual counting of lesions produces variable reproducibility. ${ }^{14,63}$

Nevertheless, our results prove to be consistent with the data found in the literature and with the pathophysiology of the lesions. The differential quantification between erythematous and hypertrophic AKs also revealed elements that favor an approach by subgroups rather than the total counts of lesions used by other authors, mainly as long as we have no knowledge of the natural history and evolution of the genesis and transformation among those subtypes.

As our study was carried out among dermatology patients in a public institution in the south of Brazil, we cannot extrapolate its results to other situations. However, the association between the use of NSAIs and AKs has already been observed in different populations; the consistency between the results of the analyses and the magnitude of the effects found favor the recognition of an association between the use of ASA and lower counts of AKs. ${ }^{41}$ Besides, the strict exclusion criteria and the use of control variables reduced the effect of selection biases.

Subsequent clinical trials with representative sample must substantiate our findings and define the role of the regular use of ASA and other NSAIs in preventing AKs.

\section{Conclusions}

The regular use of oral acetylsalicylic acid for more than six months was independently associated to a lower prevalence of actinic keratosis, especially facial and erythematous ones.

Research Ethics Committee date: 07/20/2009 (Comitê de Ética em Pesquisa em Seres Humanos do Hospital de Clínicas/UFPR) 


\section{RESUMO}

Ácido acetilsalicílico oral e prevalência de queratoses actínicas

Objetivo: Queratoses actínicas são proliferações atípicas de queratinócitos com potencial para se transformarem em carcinoma invasivo. Estudos clínicos e laboratoriais têm observado um efeito preventivo de anti-inflamatórios não hormonais no desenvolvimento de diversas neoplasias. Neste estudo, investigamos a influência do uso regular do ácido acetilsalicílico na prevalência de queratoses actínicas.

Métodos: Estudo caso-controle com pacientes dermatológicos acima de 50 anos de idade, avaliados entre 2009 e 2011. Os casos foram definidos como aqueles que estavam sob uso regular de ácido acetilsalicílico por via oral por mais de seis meses consecutivos. Avaliou-se idade, sexo, fototipo, tabagismo, uso de medicamentos, ocorrência de câncer de pele no indivíduo ou na família, hábitos de proteção e exposição solar. As queratoses actínicas foram contadas nos membros superiores e região medial da face. As contagens foram ajustadas pelas covariáveis em um modelo linear generalizado.

Resultados: Um total de 74 casos e 216 controles foi avaliado. O tempo médio de uso de ácido acetilsalićlico foi de 36 meses. Casos diferiam dos controles quanto a idade mais elevada, maior prevalência de uso de inibidores da enzima conversora da angiotensina e menos queratoses na face e membros superiores $(\mathrm{p}<0,05)$. O modelo multivariado mostrou que o uso do ácido acetilsalicílico esteve associado a contagens mais baixas de queratoses actínicas na face de queratoses não hipertróficas nos membros superiores $(\mathrm{p}<0,05)$.

Conclusão: $\mathrm{O}$ uso regular do ácido acetilsalicílico por via oral por mais de seis meses esteve associado a uma menor prevalência de queratose actínica, especialmente faciais e eritematosas.

Unitermos: queratoses actínicas, ácido acetilsalicílico, prevalência, fatores de risco.

\section{References}

1. Schmitt JV, Miot HA. Actinic keratosis: a clinical and epidemiological revision. An Bras Dermatol. 2012;87:425-34.

2. Salasche SJ. Epidemiology of actinic keratoses and squamous cell carcinoma. J Am Acad Dermatol. 2000;42:4-7.

3. Lebwohl M. Actinic keratosis: epidemiology and progression to squamous cell carcinoma. Br J Dermatol. 2003;149(Suppl 66):31-3

4. Rossi R, Mori M, Lotti T. Actinic keratosis. Int J Dermatol. 2007:46:895-904.

5. Criscione VD, Weinstock MA, Naylor MF, Luque C, Eide MJ, Bingham SF; Department of Veteran Affairs Topical Tretinoin Chemoprevention Trial Group. Actinic keratoses: Natural history and risk of malignant transformation in the Veterans Affairs Topical Tretinoin Chemoprevention Trial. Cancer. 2009;115:2523-30.

6. Frost CA, Green AC. Epidemiology of solar keratoses. Br J Dermatol 1994;131:455-64.

7. Sociedade Brasileira de Dermatologia SBD. Perfil nosológico das consultas dermatológicas no Brasil. An Bras Dermatol. 2006;81:549-58.

8. Langley RE, Burdett S, Tierney JF, Cafferty F, Parmar MK, Venning G. Aspirin and cancer: has aspirin been overlooked as an adjuvant therapy? $\mathrm{Br} \mathrm{J}$ Cancer. 2011;105:1107-13.

9. Ruder EH, Laiyemo AO, Graubard BI, Hollenbeck AR, Schatzkin A, Cross AJ. Non-steroidal anti-inflammatory drugs and colorectal cancer risk in a large, prospective cohort. Am J Gastroenterol. 2011;106:1340-50.

10. Torti DC, Christensen BC, Storm CA, Fortuny J, Perry AE, Zens MS, et al Analgesic and nonsteroidal anti-inflammatory use in relation to nonmelanoma skin cancer: a population-based case-control study. J Am Acad Dermatol. 2011;65:304-12

11. Curiel-Lewandrowski C, Nijsten T, Gomez ML, Hollestein LM, Atkins MB Stern RS. Long-term use of nonsteroidal anti-inflammatory drugs decreases the risk of cutaneous melanoma: results of a United States case-control study. J Invest Dermatol. 2011;131:1460-8.

12. Tjiu JW, Liao YH, Lin SJ, Huang YL, Tsai WL, Chu CY, et al. Cyclooxygenase-2 overexpression in human basal cell carcinoma cell line increases antiapoptosis, angiogenesis, and tumorigenesis. J Invest Dermatol. 2006;126:1143-51.

13. Fecker LF, Stockfleth E, Nindl I, Ulrich C, Forschner T, Eberle J. The role of apoptosis in therapy and prophylaxis of epithelial tumours by nonsteroidal anti-inflammatory drugs (NSAIDs). Br J Dermatol. 2007;156(Suppl 3):25-33.

14. Epstein E. Quantifying actinic keratosis: assessing the evidence. Am J Clin Dermatol. 2004;5:141-4.

15. Henderson AR. Testing experimental data for univariate normality. Clin Chim Acta. 2006;366:112-29.

16. Coxe S, West SG, Aiken LS. The analysis of count data: a gentle introduction to poisson regression and its alternatives. J Pers Assess. 2009;91:121-36.

17. Norman GR, Streiner DL. Biostatistics. The bare essentials. $3^{\text {rd }}$ ed. Shelton: People's Medical Publishing House; 2008.

18. Katz MH. Multivariable analysis. A practical guide for clinicians. $2^{\text {nd }} \mathrm{ed}$. Cambridge: Cambridge University Press; 2006.

19. Hughes MC, Williams GM, Fourtanier A, Green AC. Food intake, dietary patterns, and actinic keratoses of the skin: a longitudinal study. Am J Clin Nutr. 2009;89:1246-55

20. Mackinnon A. The use and reporting of multiple imputation in medical research - a review. J Intern Med. 2010;268:586-93.

21. SPS 17.0 for Windows. In. $17 \mathrm{ed}$. Chicago (IL): SPSS Incorporation; 2008:Statistical Package for Social Science (SPSS).

22. Ortega Calvo M, Cayuela Dominguez A. [Unconditioned logistic regression and sample size: a bibliographic review]. Rev Esp Salud Publica. 2002;76:85-93.

23. Demidenko E. Sample size determination for logistic regression revisited. Stat Med. 2007;26:3385-97.

24. Wang CH, Ouyang Q, Tang CW, Huang MH, Li X. [Effects of selective and non-selective cyclooxygenase-2 inhibitor on the growth of colon cancer cells]. Sichuan Da Xue Xue Bao Yi Xue Ban. 2006;37:547-50.

25. Leong J, Hughes-Fulford M, Rakhlin N, Habib A, Maclouf J, Goldyne ME. Cyclooxygenases in human and mouse skin and cultured human keratinocytes: association of COX-2 expression with human keratinocyte differentiation. Exp Cell Res. 1996;224:79-87.

26. Buckman SY, Gresham A, Hale P, Hruza G, Anast J, Masferrer J, et al. COX 2 expression is induced by UVB exposure in human skin: implications for the development of skin cancer. Carcinogenesis. 1998;19:723-9.

27. An KP, Athar M, Tang X, Katiyar SK, Russo J, Beech J, et al. Cyclooxygenase-2 expression in murine and human nonmelanoma skin cancers: implications for therapeutic approaches. Photochem Photobiol. 2002;76:73-80.

28. Wu Y, Liu H, Li J. Expression of p63 and cyclooxygenase-2 and their correlation in skin tumors. J Huazhong Univ Sci Technolog Med Sci. 2007;27:206-8.

29. Nijsten T, Colpaert CG, Vermeulen PB, Harris AL, Van Marck E, Lambert J Cyclooxygenase- 2 expression and angiogenesis in squamous cell carcinoma of the skin and its precursors: a paired immunohistochemical study of 35 cases. Br J Dermatol. 2004;151:837-45.

30. Tiano HF, Loftin CD, Akunda J, Lee CA, Spalding J, Sessoms A, et al Deficiency of either cyclooxygenase (COX)- 1 or COX-2 alters epidermal differentiation and reduces mouse skin tumorigenesis. Cancer Res. 2002;62:3395-401.

31. Muller-Decker K, Neufang G, Berger I, Neumann M, Marks F, Furstenberger G. Transgenic cyclooxygenase-2 overexpression sensitizes mouse skin for carcinogenesis. Proc Natl Acad Sci USA. 2002;99:12483-8. 
32. Berhane T, Halliday GM, Cooke B, Barnetson RS. Inflammation is associated with progression of actinic keratoses to squamous cell carcinomas in humans. Br J Dermatol. 2002;146:810-5.

33. Sheng H, Shao J, Morrow JD, Beauchamp RD, DuBois RN. Modulation of apoptosis and Bcl-2 expression by prostaglandin E2 in human colon cancer cells. Cancer Res. 1998;58:362-6.

34. Yano T, Zissel G, Muller-Qernheim J, Jae Shin S, Satoh H, Ichikawa T. Prostaglandin E2 reinforces the activation of Ras signal pathway in lung adenocarcinoma cells via EP3. FEBS Lett. 2002;518:154-8.

35. Yoshimoto $\mathrm{T}$, Takahashi $\mathrm{Y}$, Kinoshita $\mathrm{T}$, Sakashita $\mathrm{T}$, Inoue $\mathrm{H}$, Tanabe $\mathrm{T}$. Growth stimulation and epidermal growth factor receptor induction in cyclooxygenase-overexpressing human colon carcinoma cells. Adv Exp Med Biol. 2002;507:403-7.

36. O'Grady A, O'Kelly P, Murphy GM, Leader M, Kay E. COX-2 expression correlates with microvessel density in non-melanoma skin cancer from renal transplant recipients and immunocompetent individuals. Hum Pathol. 2004;35:1549-55.

37. Fischer SM, Lo HH, Gordon GB, Seibert K, Kelloff G, Lubet RA, et al. Chemopreventive activity of celecoxib, a specific cyclooxygenase-2 inhibitor, and indomethacin against ultraviolet light-induced skin carcinogenesis Mol Carcinog. 1999;25:231-40.

38. Orengo IF, Gerguis J, Phillips R, Guevara A, Lewis AT, Black HS. Celecoxib, a cyclooxygenase 2 inhibitor as a potential chemopreventive to UV-induced skin cancer: a study in the hairless mouse model. Arch Dermatol. 2002;138:751-5.

39. Tang X, Kim AL, Kopelovich L, Bickers DR, Athar M. Cyclooxygenase-2 inhibitor nimesulide blocks ultraviolet B-induced photocarcinogenesis in SKH-1 hairless mice. Photochem Photobiol. 2008;84:522-7.

40. Bundscherer A, Hafner C, Maisch T, Becker B, Landthaler M, Vogt T. Antiproliferative and proapoptotic effects of rapamycin and celecoxib in malignant melanoma cell lines. Oncol Rep. 2008;19:547-53.

41. Butler GJ, Neale R, Green AC, Pandeya N, Whiteman DC. Nonsteroidal antiinflammatory drugs and the risk of actinic keratoses and squamous cell cancers of the skin. J Am Acad Dermatol. 2005;53:966-72.

42. Clouser MC, Roe DJ, Foote JA, Harris RB. Effect of non-steroidal antiinflammatory drugs on non-melanoma skin cancer incidence in the SKICAPAK trial. Pharmacoepidemiol Drug Saf. 2009;18:276-83.

43. Asgari MM, Chren MM, Warton EM, Friedman GD, White E. Association between nonsteroidal anti-inflammatory drug use and cutaneous squamous cell carcinoma. Arch Dermatol. 2010;146:388-95.

44. Elmets CA, Viner JL, Pentland AP, Cantrell W, Lin HY, Bailey H, et al Chemoprevention of nonmelanoma skin cancer with celecoxib: a randomized, double-blind, placebo-controlled trial. J Natl Cancer Inst. 2010;102:183544.

45. Tang JY, Aszterbaum M, Athar M, Barsanti F, Cappola C, Estevez N, et al Basal cell carcinoma chemoprevention with nonsteroidal anti-inflammatory drugs in genetically predisposed PTCH1+/- humans and mice. Cancer Prev Res. 2010;3:25-34.

46. Krishnan K, Ruffin MT, Normolle D, Shureiqi I, Burney K, Bailey J, et al Colonic mucosal prostaglandin E2 and cyclooxygenase expression before and after low aspirin doses in subjects at high risk or at normal risk for colorectal cancer. Cancer Epidemiol Biomarkers Prev. 2001;10:447-53.
47. Stark LA, Reid K, Sansom OJ, Din FV, Guichard S, Mayer I, et al. Aspirin activates the NF-kappaB signalling pathway and induces apoptosis in intestinal neoplasia in two in vivo models of human colorectal cancer. Carcinogenesis. 2007;28:968-76

48. Goel A, Chang DK, Ricciardiello L, Gasche C, Boland CR. A novel mechanism for aspirin-mediated growth inhibition of human colon cancer cells. Clin Cancer Res. 2003;9:383-90.

49. Din FV, Stark LA, Dunlop MG. Aspirin-induced nuclear translocation of NFkappaB and apoptosis in colorectal cancer is independent of p53 status and DNA mismatch repair proficiency. Br J Cancer. 2005;92:1137-43.

50. Christian JB, Lapane KL, Hume AL, Eaton CB, Weinstock MA. Association of ACE inhibitors and angiotensin receptor blockers with keratinocyte cancer prevention in the randomized VATTC trial. J Natl Cancer Inst. 2008;100:1223-32

51. Moscarelli L, Zanazzi M, Mancini G, Rossi E, Caroti L, Rosso G, et al Keratinocyte cancer prevention with ACE inhibitors, angiotensin receptor blockers or their combination in renal transplant recipients. Clin Nephrol. 2010;73:439-45.

52. Sinha P, Logan HL, Mendenhall WM. Human papillomavirus, smoking, and head and neck cancer. Am J Otol. 2012;33:130-6.

53. Guarisi R, Sarian LO, Hammes LS, Longatto-Filho A, Derchain SF, Roteli Martins C, et al. Smoking worsens the prognosis of mild abnormalities in cervical cytology. Acta Obstet Gynecol Scand. 2009;88:514-20.

54. De Hertog SA, Wensveen CA, Bastiaens MT, Kielich CJ, Berkhout MJ, Westendorp RG, et al. Relation between smoking and skin cancer. J Clin Oncol. 2001;19:231-8.

55. Sitas F, Yu XQ, O'Connell D, Blizzard L, Otahal P, Newman L, et al. The relationship between basal and squamous cell skin cancer and smoking related cancers. BMC Res Notes. 2011;4:556.

56. Rollison DE, Iannacone MR, Messina JL, Glass LF, Giuliano AR, Roetzheim RG, et al. Case-control study of smoking and non-melanoma skin cancer. Cancer Causes Control. 2012;23(2)245-54.

57. Miot HA, Miot LD, da Costa AL, Matsuo CY, Stolf HO, Marques ME. Association between solitary keratoacanthoma and cigarette smoking: a case-control study. Dermatol Online J. 2006;12:2.

58. Beham A, Regauer S, Soyer HP, Beham-Schmid C. Keratoacanthoma: a clinically distinct variant of well differentiated squamous cell carcinoma. Adv Anat Pathol. 1998;5:269-80.

59. Quaedvlieg PJ, Tirsi E, Thissen MR, Krekels GA. Actinic keratosis: how to differentiate the good from the bad ones? Eur J Dermatol. 2006;16:335-9.

60. Thompson SC, Jolley D, Marks R. Reduction of solar keratoses by regular sunscreen use. N Engl J Med. 1993;329:1147-51

61. Hensen P, Muller ML, Haschemi R, Ständer H, Luger TA, Sunderkötter C et al. Predisposing factors of actinic keratosis in a North-West German population. Eur J Dermatol. 2009;19:345-54.

62. Ulrich C, Jurgensen JS, Degen A, Hackethal M, Ulrich M, Patel MJ, et al. Prevention of non-melanoma skin cancer in organ transplant patients by regular use of a sunscreen: a 24 months, prospective, case-control study. $\mathrm{Br}$ J Dermatol. 2009;161(Suppl 3):78-84.

63. Atkins D, Bang RH, Sternberg MR, Chen SC. Reliable methods to evaluate the burden of actinic keratoses. J Invest Dermatol. 2006;126:591-4. 